Ghana Journal of Development Studies, Volume 4, Number 2 (December 2007).

\title{
FACTORS INFLUENCING COMMERCIAL CHARCOAL PRODUCTION IN THE WEST MAMPRUSI DISTRICT OF GHANA
}

\author{
Jeffery Shekmuker Makain
}

\begin{abstract}
Department of Environmental and Resources Studies University for Development Studies, Wa Campus, Ghana

Email: jeffmakain@yahoo.com
\end{abstract}

\begin{abstract}
Charcoal production is increasingly becoming an important trade in the northern regions of Ghana in spite of its implication for deforestation and natural resources depletion. In the West Mamprusi District of northern Ghana, charcoal production is a major dry season activity in many communities. This paper examines factors influencing the increasing rate of charcoal production in the District from 1980 to 2005. Research instruments employed were: purposive and simple random sampling, direct observation; transect walks, stump count, focus group discussion, key informant and structured interviews. The study reveals that local and national organizational structures exist that monitor the natural environment of the District; community members are aware of the environmental impact of their activities, and that charcoal production is a livelihood activity of the people in the District. Findings from the research revealed that charcoal production was a full time occupation for many females (i.e., 65\%); major buyers were from urban towns in Northern and Upper East Regions; charcoal production was a major source of income and livelihood activities in the District and the work of the Forestry Commission's monitoring was effective in the forest-reserved areas. It concludes therefore that existing institutional structures have failed to implement regulations to control the effects.
\end{abstract}

KEY DESCRIPTORS: Commercial Charcoal producers, Capital, Natural Resources, Environmental Impact

\section{INTRODUCTION}

Over the past five years, close observation of the number of charcoal bags displayed by sale points (communities) along the roadside has increased from between 5 and 10 to about 50 or more bags throughout the week in the Northern Savannah Zone. This increasing number of charcoal bags is accompanied with huge piles of wood that have different values and usage for rural people. In the West Mamprusi District, the most prominent towns engaged in charcoal and wood sale are Wulugu, Nabari, Loagri, Nasia, Wungu, Kparigu and Karimenga.

Meanwhile, it has been observed that charcoal depots have increased from one to three in the Bolgatanga Municipality, one to two in Navrongo in the Kassena 
Ghana Journal of Development Studies, Volume 4, Number 2 (December 2007).

Nankana District and from one to two it Walewale in West Mamprusi District from 2000 to 2004. Moreover, field measurement carried out in December 2004, involving only stump counting in Karimenga a settlement in the forest reserve along the White Volta River Bank and Wulugu, revealed that about 50-60 trees out of about 100-125 trees per acre has been cut down or burnt by bush fire.

Natural resources such as forests, soil, grazing lands and water bodies are being gradually degraded in the Northern Region and West Mamprusi District. Environmentalists propose an outright ban on charcoal production in the area due to the destructive nature of current practices. However, attempts made to ban the production of charcoal have been unsuccessful due to the interplay of commercial interests, the high demand for the products by urban dwellers and its implications on the livelihoods of producers.

Moreover, since producers can use free raw materials (wood from natural forest) and turn them into a marketable commodity in high demand, they do not have much respect for sustaining the resource. Virtually all the charcoal produced in Ghana is by the earth mound method. Very few kilns are in use at Daboase in the Western Region and are owned by the Subri Industrial Plantations Limited.

The poor technology involved in the production of charcoal coupled with high demand by urban dwellers is not without environmental problems in West Mamprusi District, which also has economic trees such as shea, dawadawa and mangoes. Even though many attempts have been made by some groups to protect the environment in the area, little has been achieved. Sensitization and educational programmes organized by Rural Media Network (RUMNET) with support from IBIS-Ghana was focused on discriminatory felling of trees for charcoal production and training of fire volunteers to save the situation. Attempts have been made to encourage groups and individuals to enter into afforestation and agro-forestry to ensure sustainable forest resources utilization.

In spite of these efforts, the sustainable use and management of forest resources seem to have been to no avail. Hence, a study was conducted to determine the real factors accounting for the increasing rate of commercial charcoal production in the district over the past twenty-five years (1980-2005). This paper reports the key findings of the study.

The key questions addressed in this paper are: Why has commercial charcoal production become a major activity? Who are the major commercial charcoal producers? What is their major source of capital? Who are their major buyers? What kind of awareness exists on the likely impact of commercial charcoal production on the natural vegetation cover? Is there any institutional organization to check or control the erosion of the natural vegetation cover? 
Ghana Journal of Development Studies, Volume 4, Number 2 (December 2007).

\section{BACKGROUND}

West Mamprusi District is one of the fifteen administrative districts in Northern Region. It is located between longitudes $0^{\circ} 35^{\prime}$ West and $1^{\circ} 45^{\circ}$ West and Latitudes $9^{\circ}$ $55^{\circ}$. North and $10^{\circ} 35^{\prime}$ North and situated at the central northernmost part of the Northern Region. It is bordered by the Talensi-Nadam and Builsa Districts of the Upper East Region to the north and West respectively, East Mamprusi District to the East and Savelugu-Nanton to the South (West Mamprusi District Assembly (WMDA), 2003: 1).

The District has a generally undulating topography characterized by gentle slopes from northeast to southwest, with some isolated visible outcrop and uplands of not more than $10 \%$ slope. Isolated hills, which break the monotony of landscape, can be found around Karimenga, Shelinvoya and the outskirts of Wulugu (WMDA, 2003)

The climate of the district is similar to the rest of Northern Ghana, which is of the interior continental climatic type. It is characterized by a prolonged dry season and a short wet season. The two seasons are influenced by two oscillating air masses, first is the warm and dry harmattan wind, which blows in a northeastern direction across the whole area. During this period - late November to early March, rainfall is virtually absent, vapor pressure is very low and relative humidity rarely exceeds $20 \%$. Temperature is generally between $12-45^{\circ}$ Celsius (Walker, 1957).

The wet season occurs from May to October with the annual rainfall ranging between $950-1200 \mathrm{~mm}$. In addition to this low rainfall, the amount varies from year to year. Another striking characteristic is the high rate of evapo-transpiration, which data were not available at the Meteorology Department at the district, regional and national offices. But the combination of heavy run-off, high evaporation and transpiration and low infiltration rates to recharge aquifers in some areas in the district, contribute to water deficiencies especially to the west of the White Volta, the south around Fio area and eastern parts around Shelinvoya (WMDA, 2003)

Soils of the alluvial type (i.e., Savannah glycols) are found in major river valleys and drainage courses, predominantly in the west of the district along the basins of the White Volta and its tributaries. These soils are deep, fine textured and well suited for the cultivation of a wide range of crops and can allow bullocks and other form of mechanized farming (WMDA, 2003)

The vegetation is classified as Guinea Savannah Woodland is composed of short trees of varying sizes and density and grows over a dispersed cover of perennial grasses and shrubs. Climatic conditions, relief features and soil texture, which foster water logged conditions (especially in the area west of the white Volta) in the rainy season and draughty soils in the dry season tend to develop a characteristically hardy tree vegetation adapted to long periods of dry weather (WMDA, 2003). However, there are clear indications from transect walk and field inspection that the existence 
of dense woodlands and forest along the river valley (especially areas of the basin of White Volta and its tributaries) is gradually beginning to change due to the influx of people into these areas as a result of the successful control of river borne diseases such as Onchocerciases.

The District is predominantly rural with more than $70 \%$ of the population living in rural settlements with population less than 2000. The principal land uses reflect the almost total rural base of the district's economy. About $\mathbf{8 0 \%}$ of the economically active people depend on agriculture for their livelihood. Large amounts of land are put to cultivation of major crops like maize, millet, guinea corn, groundnuts and cotton (WMDA, 2003).

According to the 1984 Population Census report, the District recorded a population of 79,130 people. The 2000 Population Census recorded 117,821, with $49.7 \%$ males and 50.3 females with an urban population of $16.2 \%$. Meanwhile population density increased from $16 / \mathrm{sq} . \mathrm{km}$ in 1984 to $24 / \mathrm{sq} . \mathrm{km}$ in 2000 , an increase of $66 \%$ in less than two decades. Moreover, the population growth pattern shows an increase of $100 \%$ between $1980-8475 \%$ between $1984-2001$. These are clear indications that the mainly rural and agricultural economy of the district is putting pressure on land available not only for agriculture, but also for fuel wood flora and building materials from the woodlands.

Apparently, the rapid population growth seems to be associated highly with the predominant subsistence agricultural economy of the district and the intensive use of family labor in smallholder farms. Thus, it is likely that land in Walewale owned by individual families which is controlled by the family head, can be partitioned continuously to accommodate new family members, hence, the reduction in family farm sizes, now ranging from 0.5 to 2.4 hectares. However, it is clearly stated in the District Profile that such entitlements to land for housing and development purposes do not apply to agricultural lands. In the district, agriculture lands are not sold, hired or leased for peasant farming. All that is required is to approach the landowner with "kola money and plot of land is offered".

Moreover, increasing demand for diminishing fuel wood resources has many adverse environmental impacts. That is, when felling wood becomes scarce, people lop off branches, fell trees and even uproot seedlings, branches and herbaceous plants. Destroying forests decreases wildlife habitat, reduces ground water supplies, exposes soil to erosion, contributes to desertification and change in rainfall pattern. These environmental challenges are expected to increase in dimension and intensity with continuous commercial charcoal production in West Mamprusi District.

\section{METHODOLOGY}

Various methods were employed such as direct observation, focus group discussion key informant interview, and transect walk, field measurement and administration of 
survey questionnaires. The study communities were purposively selected from the four spheres of the district on the basis of their location to forestlands and intensity of wood fuel business, and to ensure true reflection of the district in terms of its homogeneity in language, cultural practices and major economic activities. Sampled quota was based on the population size of the selected communities. Interviewees were chosen from households through simple random selection and purposive to capture larger number of charcoal producers in each community. The purposive sampling techniques was employed to select part and full-time commercial charcoal producers from the sampled communities dominated by farmers who are not engaged in commercial charcoal production.

On the basis of these criteria, the six communities selected were: Wulugu, Nabari, Wungu, Nasia, Kparigu and Karimenga representing a cross-section of the district (Figure 1).

\section{Figure 1: Study Communities in West Mamprusi District}
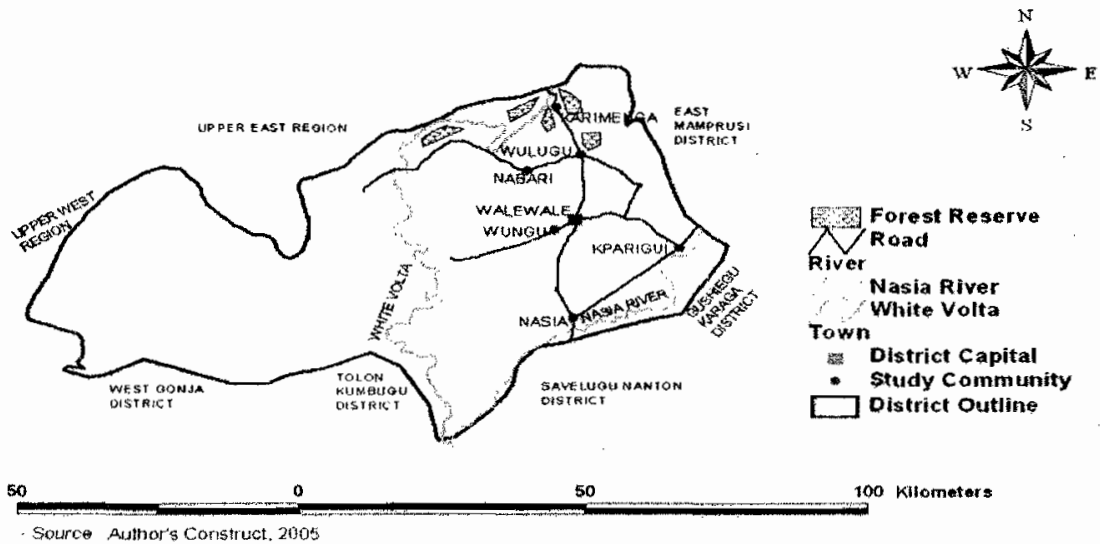

Source: Author Construct, 2005

Meanwhile, with reference to the quota application based on population size and intensity of commercial charcoal production in the community, twenty (20) questionnaires each were administered in Wulugu and Nabari; ten (10) questionnaires each in Wungu, Nasia, Kparigu and Karimenga. Thus, a total of eighty-(80) household questionnaires were administered in the district, taking cognizance of commercial charcoal producers. 
Ghana Journal of Development Studies, Volume 4, Number 2 (December 2007).

\section{KEY CONCEPTS}

This study involved the employment of several terminologies that tend to overlap in meaning among professionals of different backgrounds, thus, the need to clarify their usage in the context of this study.

\section{Charcoal}

A black porous form of carbon produced by heating wood in limited supply of oxygen (Geddes \& Grosset, 1999). For this study, charcoal is the product obtained when wet or dry wood is subjected to higher temperature under a condition of limited supply of oxygen that limits the rate of combustion.

\section{Capital}

Capital is wealth, especially large amount of money, used for producing more wealth or for starting a new business (Geddes \& Geedes, 1999. For this research, capital refers to tools like axe, hoes, cutlass, chain saw and money to pay for labor.

\section{Energy}

Energy is the capacity of a material or of radiation to do work. Energy resources are general though it encompasses electricity, gas, steam nuclear power charcoal (Geddes \& Grosset, 1999, P151). For this study, energy is the source of heat derived from burning wood product for domestic and commercial purposes in society.

\section{Environment}

Environment refers to the habitat of both living and non-living organisms. It is the surrounding especially the conditions that play a part in determining the growth and development of living organisms. Natural environment is that part of nature untouched by humans. Physical environment refers to all tangible natural and artificial features surrounding human and their habitat (Geddes \& Grosset, 1999). For this study, environment refers to the relationship that exists between humans and the physical attributes of nature in their habitat. Natural environment refers to the nonartificial features of the universe. Such features include plants, animals, soil, air and water.

\section{Impact}

Impact is the force with which one thing hits another or with which two things hit each other, or a powerful effect that something, especially something new, has on a situation or person (Geddes \& Grosset, 1999). For this research impact refers to the effect that extensive removal of the natural vegetation cover has on the savanna woodlands in West Mamprusi District. 
Ghana Journal of Development Studies, Volume 4, Number 2 (December 2007).

\section{FINDINGS:}

\section{Socio-economic Characteristics of Respondexts}

Close interactions with community members during focus group discussions, community fora and transect walks reveal that there is a clear distinction between full and part-time charcoal producers, and several factors influencing the activity in the district. These factors range from poor crop yield, seasonal employment and quick means of earning cash to supplement household food needs, pay school fees, sponsor funerals et cetera.

Engagement in commercial charcoal production was assessed as full and part time. Results in Table 1 clearly revealed that femaics ranked the highest in all the study communities, with Wulugu the highest of $65 \%$, Kparigu, $20 \%$ and Nabari $10 \%$ respectively. Males recorded $10 \%$ in Kparigu and the rest of the communities had part time producers.

\begin{tabular}{|l|l|l|l|l|l|l|c|}
\hline $\begin{array}{l}\text { COMMU- } \\
\text { NITY }\end{array}$ & $\begin{array}{l}\text { RESPON- } \\
\text { DENTS }\end{array}$ & \multicolumn{4}{l|}{ FREQUENCY } & TOTAL & $\%$ \\
\hline & & MALE & $\%$ & FEMALE & $\%$ & & \\
\hline WULUGU & 20 & 0 & 0 & 13 & 6 & 13 & 65 \\
\hline NABARI & 20 & 0 & 0 & 2 & 1 & 2 & 10 \\
\hline WUNGU & 10 & 0 & 0 & 0 & 0 & 0 & 0 \\
\hline NASIA & 10 & 0 & & 0 & 0 & 0 & 0 \\
\hline KPARIGU & 10 & 1 & 1 & 2 & 2 & 3 & 30 \\
\hline $\begin{array}{l}\text { KARI- } \\
\text { MENGA }\end{array}$ & 10 & 0 & 0 & 0 & 0 & 0 & 0 \\
\hline
\end{tabular}

Table 1: Full-time Charcoal Producers by Communities and Sex.

The high percentage ( $90 \%$ or more) of illiterate respondents, indicated in Table 2 , is highly associated with restits in table 1 , which clearly reveal that females are the highest percentage of full time charcoal producers. These findings are related to two key social issues in the development process. Firstly, the low literacy rate of females as compared to males in Ghana, $56.9 \%$ and $43.1 \%$ respectively (Fact Sheet no. 1 , June 2004). Secondly, the traditional cultural and customary practices that denies women ownership rights to land, even after the death of their husbands (Field Sur- 
Ghana Journal of Development Studies, Volume 4, Number 2 (December 2007).

vey, 2005).

\begin{tabular}{|l|l|l|l|l|l|l|l|l|l|l|l|l|}
\hline COMMUNITY & $\begin{array}{l}\text { RE- } \\
\text { SPON } \\
\text { DENT } \\
\text { S }\end{array}$ & $\begin{array}{l}\text { NO FOR- } \\
\text { MAL EDU- } \\
\text { CATION }\end{array}$ & $\begin{array}{l}\text { PRI- } \\
\text { MARY } \\
\text { EDUCA- } \\
\text { TION }\end{array}$ & $\begin{array}{l}\text { I S S } \\
\text { EDU- } \\
\text { CATIO } \\
\text { N }\end{array}$ & $\begin{array}{l}\text { SSS } \\
\text { EDU- } \\
\text { CATIO } \\
\text { N }\end{array}$ & $\begin{array}{l}\text { TERTI- } \\
\text { ARY } \\
\text { EDUCA- } \\
\text { TION }\end{array}$ \\
\hline WULUGU & 20 & 18 & 90 & 2 & 10 & 0 & 0 & 0 & 0 & 0 & 0 \\
\hline NABARI & 20 & 19 & 95 & 1 & 5 & 0 & 0 & 0 & 0 & 0 & 0 \\
\hline WUNGU & 10 & 10 & 100 & 0 & 0 & 0 & 0 & 0 & 0 & 0 & 0 \\
\hline NASIA & 10 & 10 & 100 & 0 & 0 & 0 & 0 & 0 & 0 & 0 & 0 \\
\hline KPARIGU & 10 & 10 & 100 & 0 & 0 & 0 & 0 & 0 & 0 & 0 & 0 \\
\hline KARIMENGA & 10 & 9 & 95 & 1 & 5 & 0 & 0 & 0 & 0 & 0 & 0 \\
\hline
\end{tabular}

Table 2: Respondents' Level of Formal Education by Communities

Source: Field Survey (2005)

\section{COMMERCIALIZATION OF CHARCOAL PRODUCTION}

At focus group discussions, interactions with community members and household interviews, part and full time charcoal producers as well as other members of the communities advanced several reasons. According to the full time charcoal producers the venture is lucrative for:

- The unemployed: For the part time producers, it affords them job opportunity during the dry seasons while they await the rains for rain-fed farming.

- Some community members said it is a means of earning income to buy food to supplement household food required during the long dry seasons.

- Some community members said they spend income from charcoal for school fees and clothing for wards.

- Some were of the opinion that it provides quick means of cash income due to its high demand by users.

- Widows who are full time producers, rain-fed farming was their major source of livelihood, but, after the death of their husbands and denial to rights or ownership to land, they stop farming and now live on charcoal production.

- About seven out of every ten adults (male and female) interviewed were of the view that commercialization of charcoal is due to poor crop yield over the years.

The various pieces of information outlined clearly point to two major challenges for the people in the district.

Firstly, the non-existence of alternative sources of income generating activities that culminate in hard-core poverty exemplified by food shortages at household level of 
Ghana Journal of Development Studies, Volume 4, Number 2 (December 2007).

farm families and inability to pay school fees for wards and high dependence on the natural environment for survival. Secondly, traditional customary practices which deny women outright rights to land and ownership to household land for farming after the death of their husbands.

These findings clearly attest to the Food and Agriculture Organization (1998) estimate that some 50 million agricultural households in developing countries were landless and about 738 million were near landless.

Apparently, the recent charcoal producers (1-5 years) account for $48 \%$, those between (6-10 years) $35 \%$ and those engaged in the business 10 years or more were 17 $\%$ of all the respondents. These results corroborate the respondents' observations and views about their own environmental reasoning. According to the participants, ten years ago, the vegetative cover was better able to support crop cultivation.

Hence, those who patronized charcoal production were full time charcoal producers for their livelihood. Moreover, the high demand for cash to supplement household food requirement, pay school fees in the absence of alternative income generating activities has led to the dramatic increase in the number of charcoal producers in recent years (Table 3).

\begin{tabular}{|l|l|l|l|l|l|l|l|}
\hline $\begin{array}{l}\text { COMMU- } \\
\text { NITY }\end{array}$ & $\begin{array}{l}\text { RESPON- } \\
\text { DENT }\end{array}$ & \multicolumn{5}{|l|}{ DURATION IN CHARCOAL PRODUCTION } \\
\hline & NUMBER & $1-5$ YEARS & 6 -10 YEARS & 10 + YEARS \\
\hline & & NO. & $\%$ & NO. & $\%$ & NO. & $\%$ \\
\hline WULUGU & 20 & 6 & & 8 & & 6 & \\
\hline NABARI & 20 & 6 & & 8 & & 6 & \\
\hline WUNGU & 10 & 7 & & 2 & & 1 & \\
\hline NASIA & 10 & 6 & & 4 & & - & \\
\hline KPARIGU & 10 & 5 & & 4 & & 1 & \\
\hline KARIMENGA & 10 & 8 & & 2 & & - & \\
\hline TOTAL & 80 & 38 & 48 & 28 & 35 & 14 & 17 \\
\hline
\end{tabular}

Table 3: Duration in Charcoal Production by Communities Source: Field Survey (2005)

Other factors responsible for the recent increase include advanced payment made by charcoal buyers, provision of empty sacks and free transportation cost to producers for sale of products as incentives from buyers. These conditions coupled with the high demand for charcoal in fast growing urban towns like Walewale, Bolgatanga, Nalerigu and Tamale and the ready access of the people to the savanna woodlands at no cost makes the woodlands vulnerable to excessive extraction of wood fuel with no remorse of conscience. This pathetic situation was summed up in the words of the chief of Nabari. He lamented saying " $m y$ son, if I stop them from charcoal produc- 
Ghana Journal of Development Studies, Volume 4, Number 2 (December 2007).

tion they will all runaway and leave me alone because it is a means of survival." SOURCES OF CAPITAL AND LABOUR

From close observation and key informant interview with full and part time charcoal producers, it was revealed that producers utilize material capital. The most common ones used in the district include cutlasses, axe, hoe and shovel. Whereas, in Southern Ghana financial capital is used mostly to hire labor or buy chain and motor saw for felling of trees (Nketiah, 1988).

Meanwhile, in West Mamprusi District, the charcoal venture is characterized by sole proprietorship, and their main source of labor is family support. For transportation, head loading is commonly used with few producers using donkey carts and bicycles. In Southern Ghana, labor is hired using financial capital.

\section{MAJOR BUYERS OF CHARCOAL}

Irrespective of the price, charcoal is still of high demand by households and smallscale industries as an energy source throughout the year especially in the fast growing urban towns. This is due to its advantages in the form of easy storage and quick preparation of fire compared to firewood.

According to the charcoal producers, their biggest buyers or customers come from four urban/semi urban towns in the Northern and Upper East Regions. Results from the survey revealed that customers from Bolgatanga account for $50 \%$ of the charcoal buyers, Walewale $31 \%$, Tamale $13 \%$, and Nalerigu $6 \%$. These results are true reflection of urban dwellers' high demand for charcoal as a major source of energy

Figure 2: Pereentage Distribution of Ahajor Chareoal Buyers

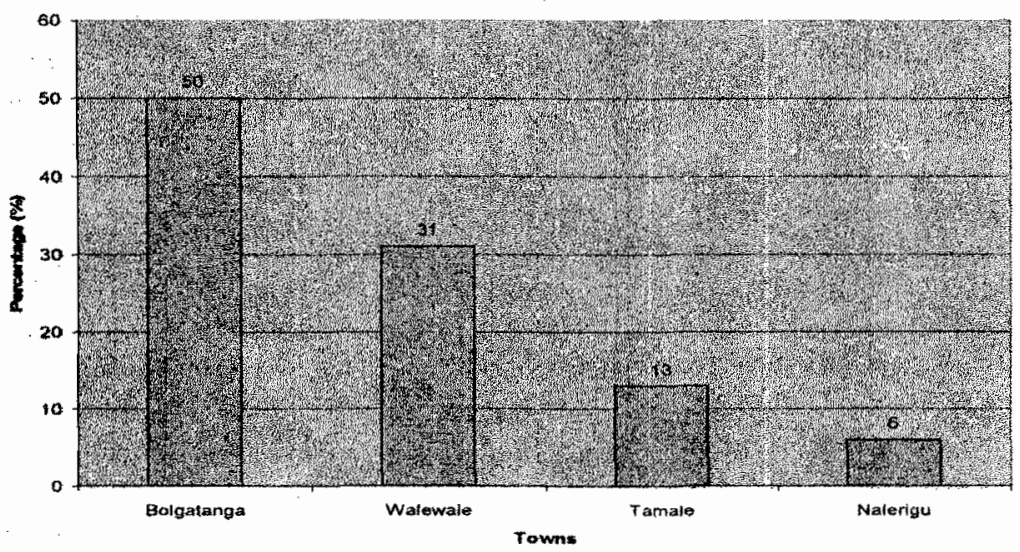

(Figure 2). 
Ghana Journal of Development Studies, Volume 4, Number 2 (December 2007).

Source: Field Survey (2005)

\section{IMPACT OF COMMERCIAL CHARCOAL PRODUCTION ON THE ENVI- RONMENT}

Information from focus group discussions, key informant interviews and direct observation revealed that there was a common denominator in the study communities with reference to land infertility. Reasons raised by community members for land infertiity included indiscriminate felling of tress for wood fuel; continuous farming on the same piece of land and uncoritrolled bush fires. These findings resonate NsiahGyabaah's (1994) assertion that the combined effects of deforestation for fire wood, charcoal, poor agricultural practices and annual uncontrolled bush fires have led to the ongoing land degradation in the Northern Ghana Guinea Savanna. This pathetic situation was summed up in the words of a widow, a 50 year-old full time charcoal producer thus, "Non Governmental Organizations including RUMNET have actually educated us well about the harmful effects of our activities on the environment but, how do we feed our households with nothing else to do?"

Information gathered from transect walks and guided tours, key informant discussions with charcoal producers clearly revealed that there is no permanent site for charcoal production in all the study communities. Thus, charcoal producers constantly move to places where selected species can be found. Reasons advanced by eight out of every ten producers interviewed were: they move to where selected species for production are available and the wood is difficult to carry to distant places since their common means of transport is head loading. These reasons are associated with the increasing distance between communities and the raw material source over the years.

From discussions with respondents, eight out of every ten producers indicated that distance to raw materials ranged between 1 to 6 kilometers. Their general perception was producers did not travel far to harvest wood for charcoal in the 1980s. At the time of this research, they expressed clearly that producers now travel beyond five kilometers in search of selected wood (Figure3).

Source: Field Survey, 2005

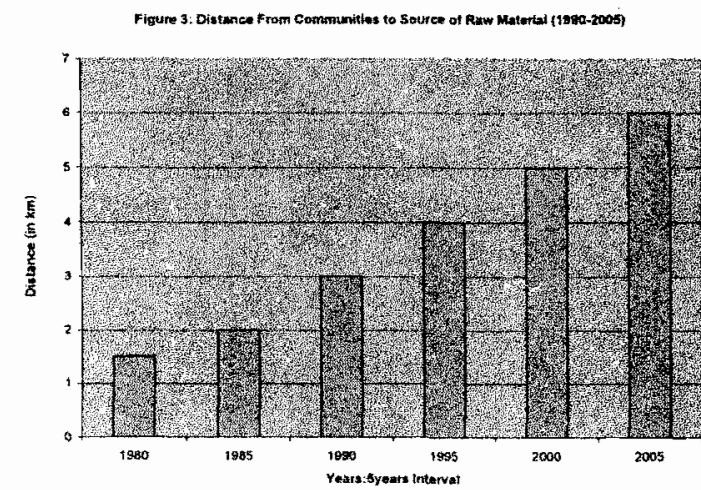


Ghana Journal of Development Studies, Volume 4, Number 2 (December 2007).

Results in Figure 3 capture the level of depletion of the savanna woodlands in the district and specifically near the study communities. In support of this observation, a triangulation process was carried out using stump count, which yielded similar results. That is, the estimated percentage of selected trees cut near the communities (clear land) was $60 \%$ as against those cut from bushy land more than five kilometers from the communities $40 \%$ (Figure 4 ).

Figure 4: Estimated Lost Trees at Wulugu and Karimenga

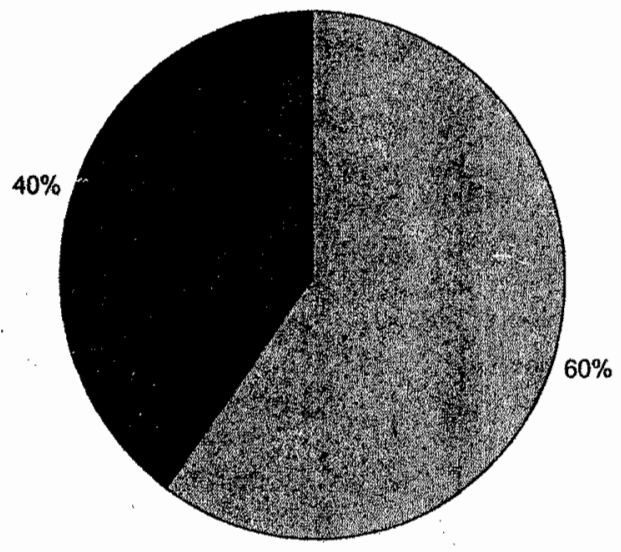

Cleared Land Bush Land

Source: Field Survey, 2005

In addition, evidence of stump count and the extent of the vegetation depletion can be seen clearly from photographs of cleared land at Wulugu, near the White Volta River forest reserved catchments areas (Figure 5). Figure 6 displays charcoal bags being packaged for the market as some buyers inspect the product before a storehouse in Wulugu. Figure 7 displays a charcoal mound in Wulugu town. This was a clear indication that charcoal production had no specific spot. Figure 8 displays the researcher closely observing heap of charcoal and bundles of roofing thatch by a hut in Wulugu town. These are clear indications of the extent of wood fuel extraction in the district either for sale as firewood or used for charcoal production to provide source of energy. 
Figure 5: Clear Area at Wulugu with Pile of Wood Ready for Market

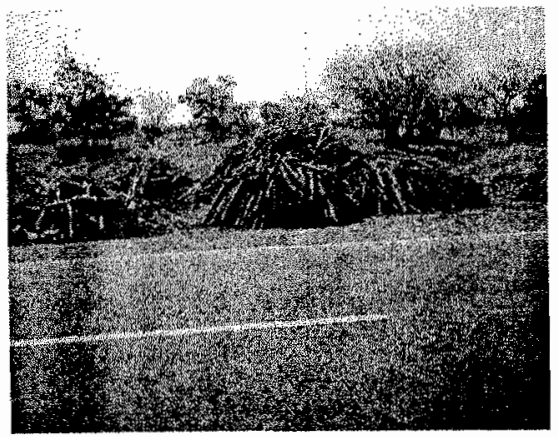

Source: Field Survey, 2005

Figure 7: Charcoal Mound in Wulugu Town

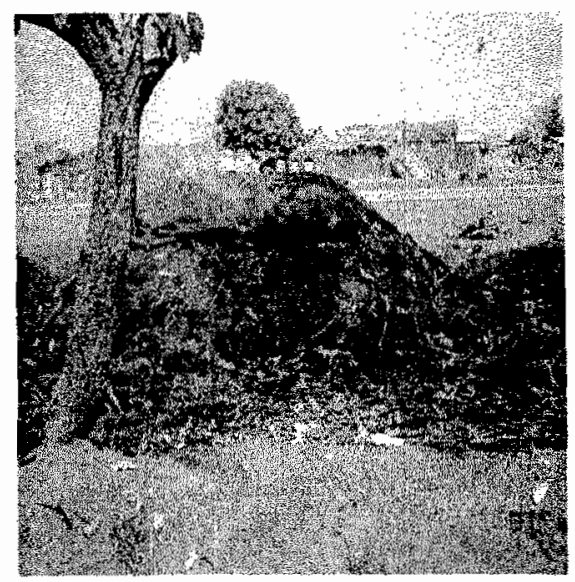

Source: Field Survey, 2005
Figure 6: Packaging Charcoal for Sale in Wulugu

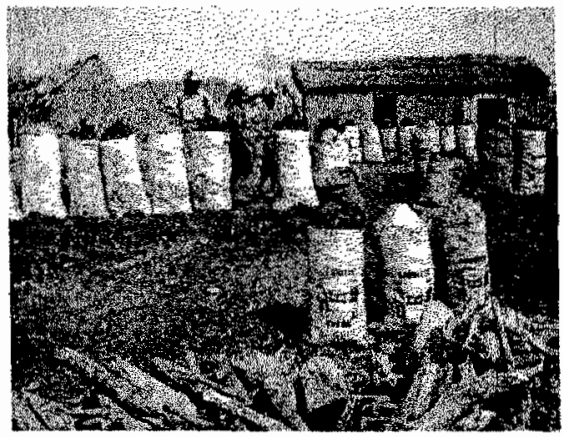

Source: Field Survey, 2005

Figure 8: Heap of Charcoal and Bundles of Roofing Thatch in Nabari

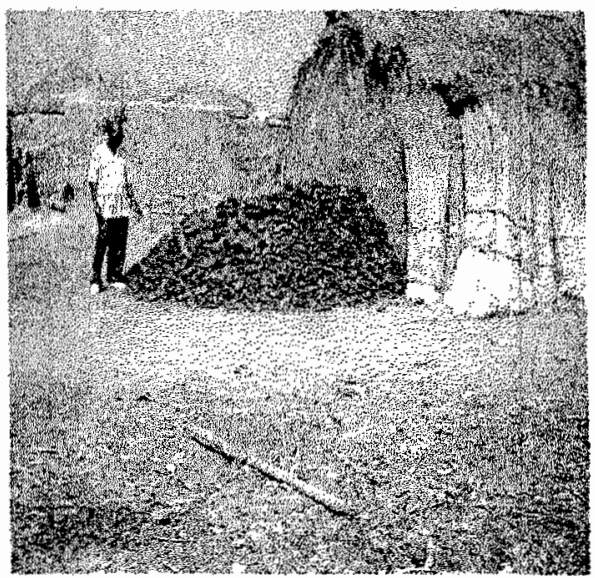

Source: Field Survey, 2005

\section{ORGANIZATIONAL MONITORING OF FUEL WOOD EXTRACTION}

According to the District Forestry Commissioner, guards from the Forestry Commission monitor and protect the forest against encroachment of all forms. The Commission considers that it is illegal to cut wood from the forest and they are making every effort to stop the practice. 
The effect of the Commission's protection and monitoring exercises was clearly reflected in the survey findings. Survey results revealed that eight out of every ten respondents cut wood for charcoal from their family farmlands, whilst the rest cut wood from the forest. A true reflection of information gathered from the Forestry Commission and the District Assembly. That is, the Tindana owns lands in the District as tradition demands, but family heads own individual sections. This may explain why cutting wood in farm lands dominate because most individual land owners are themselves charcoal producers. This finding is highly supported by the assertion of the Forestry Commission and District Assembly that charcoal production in the district is a form of livelihood to supplement low farm yields.

\section{CONCLUSION}

The study revealed that the socio-economic constraints of the community member emanate from their low level of formal educational achievement that limits their proactive utilization of available and accessible information for income generating opportunities. As such, they are compelled to exert pressure on the savannah woodlands for their livelihood. A clear example is their adherence to traditional customary practices that deny women their rights to land for livelihood activities even after the death of their husbands.

The study demonstrates that demand for charcoal by urban dwellers, poor crop yield over the two decades and very little investment required for charcoal production have increased the rate of commercial charcoal production in the district. Vivid indicators were the large number of full time females engaged in the business in recent years and increased quantity of charcoal bags displayed each day along the highway in the district.

Findings from the study revealed that the Forestry Commission was actively involved in monitoring and protecting forest woodlands in the district, but had no control over individual family land holding.

\section{RECOMMENDATIONS}

In concurrence with the findings of the research, the following are advanced in support of sustaining environmentally friendly activities in the District.

All charcoal producers be registered into a district association and a minimum tax levy of one hundred cedis $(\phi 100.00)$ per bag charged for forest resource user fee. The District Assembly could augment this user fee with technical assistance from the Forestry Commission to organize and mobilize them to establish wood lots.

The Forestry Commission and the District Assembly could institute an integrated programme for active participation of all communities in the "no bush burning and 
Ghana Journal of Development Studies, Volume 4, Number 2 (December 2007).

plant a tree campaign." At the end of every three years good practitioners win award at a district durbar.

\section{REFERENCES}

Chachu, Rex E. O. (1993). Generating Energy from Biomass: An Alternative to Fossil Fuels. A Paper Presented at the Fifth National Energy Symposium Organized at the University of Cape Coast, Ghana. Energy Research Group, Ghana.

National Population Council: (2004, June). Fact Sheets No. 1: Population of Ghana National Trends. Accra, Ghana: National Population Council.

Food and Agricultural Organization (1998), Rural Development, Special Issues, Rome, Italy.

Ghana Statistical Service (2000). Population \& Housing Census: Provisional Results. Accra, Ghana: Ghana Statistical Service.

Hollingdale (1999). Charcoal Production: A Handbook.

Makain, Jeffrey S. (2004). Broadening the Understanding of Globalization and its Impact on the Environment: The Ghanaian Situation. A Paper presented at a Symposium on Broadening the Understanding of Globalization, Tamale (Unpublished).

Mensah, Frimpong K. (1997). Wood Utilization Under Charcoal Production in Ghana.

Nketiah, K. S. (1998). The Charcoal Cycle in Ghana: A Baseline Survey (unpubublished).

Nketiah, K. S., E. B. Hagan \& S. T. Addo (1998). The Charcoal cycle in Ghana. A Baseline Survey, UNDP/National Energy Board, Ghana.

Nketiah, K. S. (1992). The Prospects for Commercial Charcoal Production from Log. ging Residues in Ghana, Accra, Ghana: Ministry of Energy.

(1987), Report on Familiarization Tour of Selected Areas of Charcoal Production and Consumption in Southem Sector of Ghana. Submitted to the Ghana Forestry Commission, Accra.

(1987a). Household Energy Consumption Survey: Experiences in Ghana. A Paper Presented at a Symposium on Renewable Energy, Legon, Ghana (unpublished). 
Ghana Jouinal of Development Studies, Volume 4, Number 2 (December 2007).

Nsiah-Gyabaah, K.(1994). Environmental Degradation and Desertification in Ghana. England, UK: Avebury.

Walker, H. O. (1957). Weather and Climate of Ghana, Ghana Meteorological Department: Department Note 5. Map (mimeographed) Accra (Unpublished).

West Mamprusi District Assembly (2003). Mamprusi West District Development Profile. 